\title{
Stage-specific feed intake restriction differentially regulates placental traits and proteome of goats
}

\author{
Qiongxian Yan $^{1,2}$, Juanzhi $\mathrm{Xu}^{1,3}$, Xiaosong $\mathrm{Wu}^{3,4 *}$, Dingding $\mathrm{Su}^{3}$ and Zhiliang $\operatorname{Tan}^{1,4 *}$ \\ ${ }^{1}$ CAS Key Laboratory of Agro-ecological Processes in Subtropical Region, Institute of Subtropical Agriculture, Chinese Academy \\ of Sciences, National Engineering Laboratory for Pollution Control and Waste Utilization in Livestock and Poultry Production, \\ Hunan Provincial Engineering Research Center for Healthy Livestock and Poultry Production, Scientific Observing and \\ Experimental Station of Animal Nutrition and Feed Science in South-Central, Ministry of Agriculture, Changsha, Hunan \\ 410125, People's Republic of China \\ ${ }^{2}$ Hunan Co-Innovation Center for Utilization of Botanical Functional Ingredients, Changsha 410128, People's Republic of China \\ ${ }^{3}$ College of Animal Sciences and Technology, Hunan Agricultural University, Changsha 410128, People's Republic of China \\ ${ }^{4}$ Hunan Co-Innovation Center of Animal Production Safety (CICAPS), Changsha, Hunan 410128, People's Republic of China
}

(Submitted 23 October 2017 - Final revision received 26 February 2018 - Accepted 27 February 2018)

\section{Abstract}

A total of twenty-four healthy twin-bearing Liuyang black goats were allocated to two trials. In Trial 1, twelve goats received either the control diet (CG, $n$ 6, $100 \%$ feed) or restricted diet (RG, $n$ 6, 60\% feed of CG) from gestation days 26 to 65 after synchronisation. In Trial 2 , the remaining goats were randomly and equally divided into two treatments: CG and RG from days 95 to 125 of gestation. Placental traits, fetal weight, serum parameters, nitric oxide (NO), angiogenesis gene expression and cotyledon proteome were measured at the end of each trial. In early pregnancy, the total and relative weights of placenta, uterine caruncle and cotyledon, as well as fetus, were increased $(P<0 \cdot 05)$ in RG. The NO content in maternal serum was also increased $(P<0.05)$ in RG. In all, fifty differentially expressed proteins were identified in cotyledon. The up-regulated proteins are related to proliferation and fission of trophoblast cell and the placenta angiogenesis. During the late pregnancy trial, placental weight was increased $(P<0.05)$ in RG, but weight of the fetus was decreased $(P<0 \cdot 05)$. The capillary density in the cotyledon was also decreased $(P<0 \cdot 01)$. A total of fifty-eight proteins were differentially expressed in cotyledon. The up-regulated proteins in RG are related to placenta formation, blood flow regulation and embryonic development. These results indicated that feed intake restriction during gestation influenced the placental and fetal development in a stage-dependent manner. These findings have important implications for developing novel nutrient management strategies in goat production.

\section{Key words: Placenta: Feed intake restriction: Capillary: Proteomics: Pregnant goats}

In mammals, the placenta is a bidirectional exchange organ that provides metabolic substrates for fetus growth ${ }^{(1)}$, and also removes waste products of the fetus. Placental structures can be classified into hemochorial and epitheliochorial types ${ }^{(2-4)}$. The placenta of humans, rodents and primates belongs to the former and consists of three fetal cellular layers: the syncytiotrophoblast, villous stromal tissue and capillary endothelium ${ }^{(5)}$. Other species, such as ruminants, monogastric animals and carnivores, have an epitheliochorial type of placenta, whereas the placenta of ruminants is quite different from that of monogastric animals in anatomy and belongs to cotyledonary and synepitheliochorial placenta ${ }^{(6)}$ where fetomaternal exchange takes place at discrete sites named placentomes. Each placentome is divided into the maternal portion called uterine caruncle (endometrial depression) and fetal portion named cotyledon (adhesions in group villi caruncle). There is a large amount of evidence showing that the anatomy, physiology, endocrinology, blood flow and vascularity of the first-trimester placenta are different from the placenta of the second and third trimesters ${ }^{(7-14)}$. Hence, placental functions vary with stages of development and the demands of the fetus.

The placenta has been recognised as playing important roles in nutritional programming of adult diseases ${ }^{(15)}$, either via dietary modulation of the placental transport of hormones ${ }^{(16)}$ or variation in the delivery of key substrates to the developing fetus ${ }^{(17)}$. In addition, placental development and function are also related to neonatal behaviour of lambs and goats ${ }^{(18,19)}$. Therefore, the placenta may be the centre of the response to maternal undernutrition and the transfer of signals of adverse conditions from mother to fetus.

Abbreviations: AKT, non-specific serine/threonine protein kinase; CG, control group; iTRAQ, isobaric tag for relative absolute quantitation; NO, nitric oxide; NOS, nitric oxide synthase; PI3K, phosphatidylinositol 3 kinase; PLCG2, 1-phosphatidylinositol 4,5-bisphosphate phosphodiesterase $\gamma$-2; RG, restricted group; RHOC, Rho-related GTP-binding protein rhoc; VDAC1, voltage-dependent anion-selective channel protein 1; VEGF, vascular endothelial growth factor.

* Corresponding authors: Z. Tan, email zltan@isa.ac.cn; X. Wu, email wuxiaosong529@126.com 
Maternal nutrition during gestation plays an essential role in the regulation of placental development in ruminants. Maternal protein restriction during mid-gestation and late gestation influences the placental structure and organisation in rats and mice ${ }^{(20-23)}$, whereas protein limitation at early pregnancy alters the placental growth in bovine ${ }^{(24)}$. Energy deprivation in pregnant sheep can also affect placental weight ${ }^{(25,26)}$ and morphology ${ }^{(27)}$ in a stage-dependent manner. High dietary intake during early to mid-pregnancy has been demonstrated to influence the capillary development in the fetal portion of the placenta in adolescent sheep ${ }^{(28)}$. Although studies linking dietary nutrition and placental development have been carried out in bovine, sheep and other mammals, very few studies have addressed the placenta traits and angiogenesis gene expression in gestational goats affected by undernutrition.

Placentome growth in terms of mass and net cellular proliferation reaches a maximum by approximately day 80 of gestation $^{(29)}$ (total gestation $150 \mathrm{~d}$ for goats), implying that placental size and function in later gestation may be substantially uninfluenced in goats. Therefore, the hypothesis for this study using goats as the experimental animal model was that feed intake restriction at two critical time points during pregnancy differently affects fetal growth, placental traits, angiogenesis gene expression and proteome. Therein, day 65 represents the early stage before the placenta attains the maximal weight, and day 125 corresponds to the period of rapid fetal growth when the placenta does not gain weight ${ }^{(29,30)}$. Our study provides a theoretical basis for the rational feeding and management of pregnant goat periods of feed shortage.

\section{Methods}

All procedures, including animal welfare, husbandry and experimental procedures used in this study, were approved by the Animal Care Committee, Institute of Subtropical Agriculture, the Chinese Academy of Sciences, Changsha, China.

\section{Experimental design and sampling}

Experimental diets were formulated according to the Feeding Standard of Meat-producing Goats (NY/T816-2004). Ingredients and nutrient compositions of the diets are presented in Table 1. Ration composition included forage and concentrate. Fresh Miscanthus was selected as forage, cut into small pieces and mixed with concentrate before feeding. All goats were fed in two equal amounts daily at 08.00 and 17.00 hours, and had free access to clean water.

In all, twenty-four Xiangdong black goats (a local breed in Liuyang, a city in south China) with similar age (2.0 (sD 0.3 ) years old) and parity were used as experimental animals. The goats were oestrous-synchronised. A total of twelve twinbearing pregnancies were designated as early pregnant trial animals (body weight (BW) 31.2 (SD 8.1 ) kg, trial 1), and the other twelve twin-bearing goats as late-pregnant test animals (BW $36 \cdot 0(\mathrm{sD} 8 \cdot 2) \mathrm{kg}$, trial 2). The nutritional treatment for the early-pregnant trial animals ran from days 26 to 65 after synchronisation, and for the late pregnancy trial animals from days 96 to 125 . At the beginning of the test, all the pregnancies had free access to the ration until day 22 (trial 1 ) or day 92
Table 1. Ingredients and composition of the experimental diets (DM basis)

\begin{tabular}{lcc}
\hline Items & Trial 1 & Trial 2 \\
\hline Ingredients (\%) & & \\
Miscanthus & 60.0 & 40.0 \\
Maize & 26.8 & $40 \cdot 2$ \\
Soyabean meal & $8 \cdot 26$ & 12.4 \\
Fat powder & 3.20 & 4.80 \\
Calcium bicarbonate & 0.372 & 0.558 \\
Calcium carbonate & 0.388 & 0.582 \\
Sodium chloride & 0.180 & 0.270 \\
Premix & 0.800 & 1.20 \\
Nutrient level (\%) & & \\
Metabolic energy (MJ/kg DM) & 11.5 & 12.0 \\
Crude protein & 11.5 & 12.6 \\
Ca & 0.550 & 0.593 \\
P & 0.204 & 0.277 \\
\hline
\end{tabular}

* Per kg of premix contains vitamin A $95000 \mathrm{IU}$, vitamin D $17500 \mathrm{IU}$, vitamin E $18000 \mathrm{IU}, \mathrm{MgSO}_{4} \cdot \mathrm{H}_{2} \mathrm{O} 119 \mathrm{~g}, \mathrm{FeSO}_{4} .7 \mathrm{H}_{2} \mathrm{O} 2.5 \mathrm{~g}, \mathrm{CuSO}_{4} .5 \mathrm{H}_{2} \mathrm{O} 0.8 \mathrm{~g}, \mathrm{MnSO}_{4} \cdot \mathrm{H}_{2} \mathrm{O}$ $3 \mathrm{~g}, \mathrm{ZnSO}_{4} \cdot \mathrm{H}_{2} \mathrm{O} 5 \mathrm{~g}, \mathrm{Na}_{2} \mathrm{SeO}_{3} 10 \mathrm{mg}, \mathrm{KI} 40 \mathrm{mg}, \mathrm{CoCl}_{2} \cdot 6 \mathrm{H}_{2} \mathrm{O} 30 \mathrm{mg}$.

(trial 2) and then randomly divided into the control group (CG, $n 6,100 \%$ feed) and the restricted group (RG, $n 6,60 \%$ feed of CG), respectively. Each goat was housed in a single cage, adapted to the experimental diets for three days and daily feed intake was calculated.

All the goats were fasted for $12 \mathrm{~h}$ before sampling. Maternal blood samples were collected by the jugular vein from both groups into heparinised tubes, kept for $2 \mathrm{~h}$ at room temperature and then centrifuged at $3000 \mathrm{~g}$ for $10 \mathrm{~min}$ at $4^{\circ} \mathrm{C}$. The supernatant serum was collected and analysed for nitric oxide (NO) content immediately. The remaining samples were stored at $-80^{\circ} \mathrm{C}$ for subsequent analysis. After blood sampling, goats were weighed, bled and slaughtered. The entire placenta of each goat was weighed. Samples of placental tissue from the area that surrounded the umbilical cord site of attachment to the uterine epithelium of each fetus were collected avoiding blood vessels. Samples were rinsed with cold sterile saline and put on ice. Six placentomes of similar size were obtained for each umbilical cord. Next, uterine caruncle and cotyledon were separated, weighed and counted. Uterine caruncle samples were quickly wrapped with sterilised tinfoil, frozen in liquid nitrogen and stored at $-80^{\circ} \mathrm{C}$ for further analysis. Cotyledon samples in late-pregnant test (trial 2) that were close to $1 \times 1 \mathrm{~cm}^{2}$ were collected and washed with PBS (containing $0.85 \% \mathrm{NaCl}, 1.4 \mathrm{~mm} \mathrm{KH}_{2} \mathrm{PO}_{4}$ and $8 \mathrm{~mm} \mathrm{Na}_{2} \mathrm{HPO}_{4}, \mathrm{pH}=7.4$ ), fixed in $10 \%$ formalin $(\mathrm{v} / \mathrm{v})$ for $1 \mathrm{~d}$, embedded in paraffin wax and stored at $4{ }^{\circ} \mathrm{C}$ until further immunohistochemistry analysis. Placental relative weight was defined as the ratio of placental weight:goat body weight. Relative weight of uterine caruncle or cotyledon was calculated as the ratio of uterine caruncle or cotyledon weight:placental weight. Average weight of uterine caruncle or cotyledon meant the average weight of each uterine caruncle or cotyledon. Density of cotyledon was calculated as the number of cotyledons per gram placental weight.

\section{Serum parameters and nitric oxide determination}

Serum vascular endothelial growth factor (VEGF) level was determined using an ELISA kit (Donggeboye Biological Technology Co., Ltd). Total bile acid (TBA), nitric oxide synthase 
(NOS) and NO contents in serum samples were analysed by colorimetric method of biochemical kits (Nanjing Jiancheng Bioengineering Institute) according to the manufacturer's instructions. Uterine caruncle and cotyledon tissues were homogenised in a high-speed blender, centrifuged (12 $000 \mathrm{rpm} /$ min, $\left.4^{\circ} \mathrm{C}, 1 \mathrm{~h}\right)$ and the supernatants were obtained and then analysed for NO level by nitrate reductase method, same as serum samples. Total protein concentrations of caruncle and cotyledon tissues were detected using the BCA kit (Beyotime Institute of Biotechnology).

\section{Immunohistochemical analysis}

Pre-embedded samples were cut into sections of $5-\mu \mathrm{m}$ thickness using a manual rotary microtome (Leica RM2235; Leica Microsystems) and adhered to positively charged adhesion slides (Beyotime). The following procedures were performed according to the instructions of immunohistochemical kit manufacturer. In brief, slides were dewaxed and rehydrated, and then incubated with primary antibody CD34 (primary antibody from rabbit; Aviva Systems Biology) at $4{ }^{\circ} \mathrm{C}$ overnight. After washing, slides were incubated with HPR (anti-rabbit from instant IHC kits; Sangon Biotech) at $37^{\circ} \mathrm{C}$ for $30 \mathrm{~min}$. Negative control was conducted with PBS instead of primary antibody. There was no positive dye presented in the negative control, demonstrating that the antibody we used had reliable specificity. Microvessel density was determined by light microscopy in areas of staining sections containing the greatest number of capillaries and small venules (microvessels) per area. Briefly, the vascular hotspots were identified at low power (100x). Then the areas having the greatest number of CD34 antigen staining microvessels were identified. Individual microvessel counts were observed using a $400 \times$ field within the hotspot, and at least five different areas were selected in each section. Any endothelial cell or endothelial cell cluster being positive for CD34 antigen and clearly separate from an adjacent cluster was considered to be a single, countable microvessel ${ }^{(31)}$. Results were expressed as the average number of microvessels identified by two experimenters within five 400x fields.

\section{Quantitative real-time PCR}

Total RNA was extracted from uterine caruncle and cotyledon tissues using TRIZOL (Invitrogen) according to the manufacturer's instructions. After genomic DNA was eliminated by digestion with
DNase I (Thermo Scientific), the RNA quality and quantity were determined using NanoDrop 2000 (Thermo Scientific), and all RNA samples showed A260/A280 values within the range of 1.9$2 \cdot 0$. In addition, the integrity of collected RNA was analysed with gel electrophoresis. Next, $1 \mu \mathrm{g}$ of the extracted RNA was reversetranscribed to synthesise tissue-specific complementary DNA (cDNA) using the PrimeScript ${ }^{\mathrm{TM}} \mathrm{RT}$ reagent Kit (Takara,) immediately. The prepared cDNA samples were stored at $-20^{\circ} \mathrm{C}$ until subsequent quantitative real-time PCR analysis.

For relative quantification of gene expression, the ABI Prism 7900 HT Fast real-time PCR System (Applied Biosystems) was used. Primers were designed using the Primer 3 plus program, and sequences are listed in Table 2 . The specificity of designed primers was checked by online Primer-BLAST (NCBI) and subsequent gel electrophoresis analysis for the proper product size, as well as melt curve analysis during quantitative real-time PCR. The reaction system, thermal profile for all reactions and fluorescence monitoring time were the same as our previous detection ${ }^{(32)}$. Each realtime reaction was completed with a melting curve analysis to ensure the specificity of the reaction. All the samples were analysed in duplicate, and the relative amount of each specific transcript was obtained after normalisation against the endogenous control $\beta$-actin. The relative changes in mRNA expression levels were calculated according to the $2^{-\Delta \Delta C_{t}} \operatorname{method}^{(33)}$, where $\Delta \Delta C_{t}$ $($ sample - control $)=\left(C_{t}\right.$ target gene $-C_{t} \beta$-actin $)$ for the sample ( $C_{t}$ target gene $-C_{t} \beta$-actin) for the control.

\section{Protein lysis, digestion and isobaric tag for relative absolute quantitation proteomics analysis}

To extract proteins from placental samples, frozen and ground tissues were incubated in a lysis buffer containing $7 \mathrm{~m}$ urea, $2 \mathrm{M}$ thiourea, $100 \mathrm{~mm}$ DTT, $5 \% \mathrm{SDS}^{(34)}$ and protease inhibitor cocktail (each tablet is sufficient for a volume of $50 \mathrm{ml}$ of extraction solution, Roche Diagnostics Ltd) at $4^{\circ} \mathrm{C}$ for $1 \mathrm{~h}$, and then insoluble molecules were removed by centrifugation at $40000 \boldsymbol{g}$ for $1 \mathrm{~h}$ at $4^{\circ} \mathrm{C}$. The supernatant was collected, and protein concentration was determined by the RC DC Protein Assay (Bio-Rad Laboratories, Inc.). The samples were stored at $-80^{\circ} \mathrm{C}$ until use.

In-solution digestion of protein and isobaric tag for relative absolute quantitation labelling

Total proteins of placental samples were reduced with $5 \mathrm{~mm}$ TRIS-(2-carboxyethyl) phosphine at $60^{\circ} \mathrm{C}$ and then alkylated

Table 2. Information of primers used in the real-time quantitative PCR

\begin{tabular}{lllc}
\hline Genes & Accession no. & Primer sequences (5'-3') & Length (bp) \\
\hline VEGFA & NM_001287034.1 & F:CCCGGTATAAATCCTGGAGCG & 138 \\
VEGFr2 & XM_005681629.3 & R:TTAACTCAAGCTGCCTCGCC & 115 \\
NOS1 & F:TGCCTACCTCACCTGTTTCC & 160 \\
NOS2 & R:CGGCTCTTTCGCTTACTGTT & 118 \\
B-Actin & XM_013971952.2 & F:GACGGCAAGTCACACAAACC & 161 \\
& AF481159.1 & F:GACTGCCACCTTGCTCACTC & 161 \\
\hline
\end{tabular}

VEGFA, vascular endothelial growth factor A; F, forward; R, reverse; NOS1, nitric oxide synthase 1; NOS2, nitric oxide synthase 2. 
with 10 mm methyl methanethiosulfonate (MMTS) for $30 \mathrm{~min}$ at room temperature. After the proteins were digested overnight at $37^{\circ} \mathrm{C}$ with sequencing-grade modified porcine trypsin (Promega), the peptides were dried in a SpeedVac and stored at $-80^{\circ} \mathrm{C}$ until further use. For isobaric tag for relative absolute quantitation (iTRAQ) labelling, the tryptic peptides were reconstituted in ITRAQ reagent buffer, and the four groups of tissue extracts were separately labelled with eight different iTRAQ labelling reagents (for goats in Trial 1: C1:113, C2:114, R1:115, R2:116, R3:117, R4:118, C3:119, C4:121; for goats in Trial 2: C1:113, C2:114, C3:115, C4:116, R1:117, R2:118, R3:119, $\mathrm{R} 4: 121$ ), according to the manufacturer's instructions (Applied Biosystems Inc.). The labelled samples of each trial were then mixed and dried.

\section{Off-line two-dimensional liquid chromatography-MS/MS}

The mixed peptides were fractionated by strong cation exchange chromatography on a 20AD HPLC system (Shimadzu) using a polysulfoethyl column $(2 \cdot 1 \times 100 \mathrm{~mm}, 5 \mu \mathrm{m}, 300 \AA$; ; The Nest Group Inc.). In brief, the mixed peptides were desalted with Sep-Pak Cartridge (Waters), diluted with the loading buffer (10 $\mathrm{mm} \mathrm{KH}_{2} \mathrm{PO}_{4}$ in $25 \%$ acetonitrile, $\mathrm{pH} 2 \cdot 8$ ) and loaded onto the column. Buffer A was identical in composition to the loading buffer, and buffer B was same as buffer A except containing $350 \mathrm{~mm} \mathrm{KCl}$. Separation was performed using a linear binary gradient of $0-80 \%$ buffer $\mathrm{B}$ in buffer $\mathrm{A}$ at a flow rate of $200 \mu \mathrm{l} / \mathrm{min}$ for $60 \mathrm{~min}$. The absorbance at 214 and $280 \mathrm{~nm}$ was monitored, and a total of twenty strong cation exchange fractions were collected along the gradient.

Each fraction was dried down by the rotary vacuum concentrator, and then dissolved in solvent A $(5 \%$ acetonitrile and $0 \cdot 1 \%$ formic acid) and analysed on TripleTOF 5600 systems (AB SCIEX) in an information-dependent mode. In brief, peptides were separated on a reverse-phase column (ZORBAX 300SBC18 column, $5 \mu \mathrm{m}, 300 \AA$, $0 \cdot 1 \times 15 \mathrm{~mm}$; Micromass) using an Eksigent 1D PLUS system (AB SCIEX) at an analytical flow rate of $300 \mathrm{nl} / \mathrm{min}$. The peptides were separated with a $120-\mathrm{min}$ linear gradient from 5 to $40 \%$ solvent B ( $0 \cdot 1 \%$ formic acid/90\% acetonitrile). Survey scans were acquired from 400 to 1500 with up to fifteen precursors selected for MS/MS and dynamic exclusion for $20 \mathrm{~s}$

\section{Protein identification, grouping, quantitation and bioinformatic analysis}

Protein identification, grouping and quantitation were performed using Paragon and Pro Group algorithm in ProteinPilot $^{\mathrm{TM}} 4.2$ (Applied Biosystems). The data analysis parameters were set as follows: (1) Sample Type, iTRAQ 8plex (Peptide Labelled); (2) Cysteine Alkylation, MMTS; (3) Digestion, Trypsin; (4) Instrument, TripleTOF 5600; (5) Special Factors, None; (6) Species, Homo sapiens; (7) ID Focus, Biological modifications; (8) Database, NCBI Capra hircus database (release Nov 2015); (9) Search Effort, Thorough; (10) Max missed cleavages; (11) FDR Analysis, Yes; (12) User-Modified Parameter Files, No; (13) Bias Correction, Auto; (14) Background Correction, Yes. Identified proteins were grouped by the software to minimise redundancy. All peptides used for the calculation of protein ratios were unique to the given protein or proteins within the group, and peptides that were common to other isoforms or proteins of the same family were ignored. A decoy database search strategy was adopted to estimate the false discovery rate (FDR) for peptide identification. For our iTRAQ experiments, a strict unused confidence score cut-off is $1 \cdot 3$, which corresponds to a peptide confidence level of $95 \%$. With this filter, the corresponding FDR was calculated by searching against a concatenated reversed database. The results were then exported into Microsoft Excel for manual data interpretation.

Functional analysis of differentially expressed proteins identified was conducted using Gene Ontology annotation (http:// www.geneontology.org/) and proteins were categorised according to their biological process, molecular function and cellular localisation. The COG database (NCBI) and Ingenuity Pathway Analysis (content version: 17199142) were used to classify these identified proteins and enrich pathways related and networks.

\section{Statistical analysis}

The general linear model procedure of SPSS 21 Statistical Software (SPSS Inc.) was used for statistical analysis. Dietary treatment was used as the fixed effect, and goat was the random effect. Fetal weight, placental traits, serum parameters and gene expression data were analysed by covariance analysis using feed intake/(mother goat initial weight $)^{0.75}$ as the covariate. Data are presented as means and standard deviations. $P$ values $<0.05$ were considered significant.

\section{Results}

\section{Placental traits and fetal weight}

During the early pregnancy trial, total weight and relative weight of placenta, uterine caruncle and cotyledon, and fetal weight in RG were increased $(P<0.05$, Table 3$)$. During late pregnancy (trial 2), the placental weight was increased $(P<0.05)$ in $\mathrm{RG}$, but the weight of fetal goat in RG was decreased $(P<0.05)$, and the capillary density in the cotyledon in $\mathrm{RG}$ was also decreased $(P<0 \cdot 01$, Fig. 1$)$.

\section{Serum parameter and placental nitric oxide}

During early pregnancy, the content of serum NO in maternal goats in RG was increased $(P<0 \cdot 05$, Table 4$)$. The VEGF, TBA, inducible NOS (INOS) and total NOS in the serum, and NO contents in uterine caruncle and cotyledon in RG, were not affected $(P>0.05)$. During late pregnancy, intake restriction had no effect $(P>0.05)$ on the serum parameters and placental NO concentration.

\section{Angiogenesis gene expression in the uterine caruncle and cotyledon}

As shown in Table 5, the mRNA expression of genes associated with angiogenesis in the uterine caruncle and cotyledon of RG goats, including VEGFA, kinase insert domain receptor, NOS1 and NOS2, were not affected $(P>0 \cdot 05)$. 
Table 3. Placental traits of pregnant goats and body weight of the fetuses $\dagger$ (Mean values and standard deviations)

\begin{tabular}{|c|c|c|c|c|c|c|c|c|}
\hline \multirow[b]{3}{*}{ Items } & \multicolumn{4}{|c|}{ Trial 1} & \multicolumn{4}{|c|}{ Trial 2} \\
\hline & \multicolumn{2}{|c|}{ CG } & \multicolumn{2}{|c|}{$R G$} & \multicolumn{2}{|c|}{$\mathrm{CG}$} & \multicolumn{2}{|c|}{$R G$} \\
\hline & Mean & SD & Mean & SD & Mean & SD & Mean & SD \\
\hline \multicolumn{9}{|l|}{ Placenta } \\
\hline Total weight (g) & 455 & 165 & $746^{\star}$ & 128 & 1328 & 436 & $1358^{*}$ & 133 \\
\hline Relative weight & 1.27 & 0.40 & $2 \cdot 72^{\star \star}$ & 0.39 & 3.32 & 0.36 & 3.56 & 0.46 \\
\hline \multicolumn{9}{|l|}{ Uterine caruncle } \\
\hline Total weight (g) & 122 & 7.53 & $207^{\star}$ & 31.62 & 287 & 36.5 & 381 & $54 \cdot 2$ \\
\hline Relative weight & $22 \cdot 8$ & $4 \cdot 17$ & $27.90^{\star}$ & 4.87 & $30 \cdot 1$ & 6.66 & 27.6 & $2 \cdot 61$ \\
\hline Number & 98.8 & $30 \cdot 4$ & 129 & $19 \cdot 0$ & 122 & $18 \cdot 6$ & 113 & $12 \cdot 6$ \\
\hline Average weight & 1.52 & 0.71 & 2.09 & 0.71 & 2.96 & 0.99 & 3.45 & 0.30 \\
\hline \multicolumn{9}{|l|}{ Cotyledon } \\
\hline Total weight $(\mathrm{g})$ & 57.9 & $18 \cdot 9$ & $177^{\star}$ & $64 \cdot 8$ & 162 & $74 \cdot 1$ & 207 & $18 \cdot 8$ \\
\hline Relative weight & 11.4 & 2.43 & $20.9^{* \star}$ & 3.40 & 13.7 & 1.68 & 14.5 & 1.23 \\
\hline Number & 98.4 & $31 \cdot 6$ & 133 & $25 \cdot 8$ & 122 & $18 \cdot 7$ & 115 & $12 \cdot 8$ \\
\hline Average weight & 0.820 & 0.40 & 1.54 & 0.57 & 1.07 & 0.50 & 1.69 & 0.45 \\
\hline Density & 0.160 & 0.05 & 0.16 & 0.03 & 0.10 & 0.05 & $0 \cdot 10$ & 0.03 \\
\hline Fetal weight $(\mathrm{g})$ & 33.3 & 9.59 & $76 \cdot 1^{\star \star}$ & 14.9 & 2015 & 463 & $1490^{*}$ & 405 \\
\hline Fetal:placental weight ratio & 0.138 & 0.03 & 0.204 & 0.05 & 2.36 & 0.33 & 2.39 & 0.44 \\
\hline
\end{tabular}

$C G$, control group; RG, restricted group. Means: ${ }^{\star} P<0.05,{ }^{\star *} P<0.01$. † $n$ 6: $\mathrm{CG}$ and $\mathrm{RG}$.
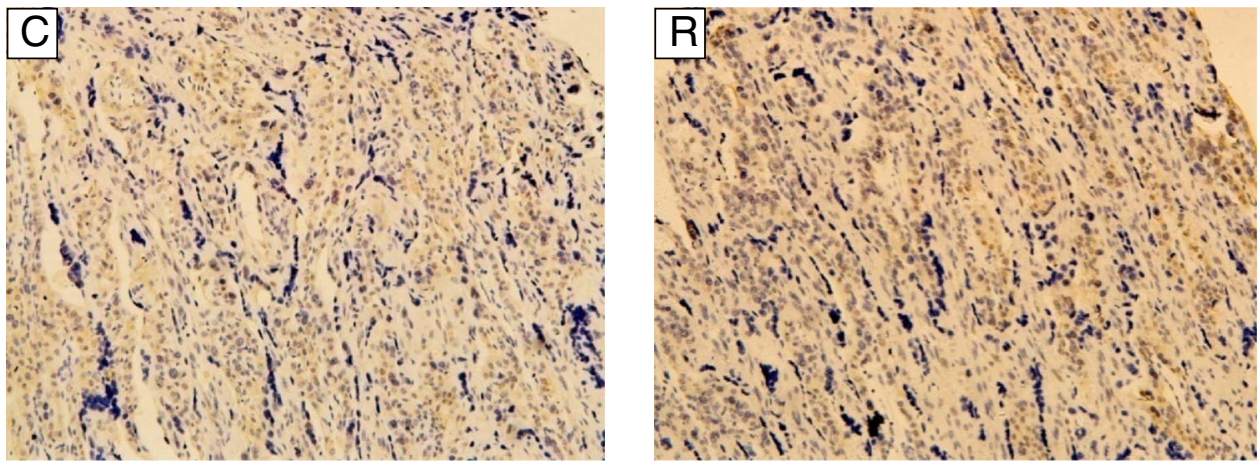

Fig. 1. Distribution of blood vessels in the cotyledon of goats during late pregnancy (400x). CD34 expression (brown) in the placental cotyledon of goats in control (C) group was 38.80 (SD 1.33) villus blood vessels per sight, whereas in restricted (R) group it was 29.06 (SD 1.00) villus blood vessels per sight $(P<0.01)$.

\section{Protein expression in the cotyledon}

A total of fifty differentially expressed proteins were detected in the placental cotyledon during early pregnancy (Table 6 ), therein twenty-seven proteins were up-regulated and twenty-three proteins were down-regulated. Functional classification (Fig. 2(a)) showed that the differentially expressed proteins were mainly involved in transcription, replication, recombination and repair, post-translational modification, protein turnover, chaperones and signal transduction mechanisms. Further analysis (Fig. 3(a)) showed that most up-regulated proteins were located in extracellular exosome, cytoplasm and membrane, and functioned as protein and metal ion binding, hydrolase and oxidoreductase activities and participated in oxidation-reduction, transport and carbohydrate metabolic processes. Meanwhile, most downregulated proteins were membrane-, cytoplasm- and nucleusassociated, involved in ATP, protein and nueleotide binding, and in charge of regulation of DNA-templated transcription, signal transduction and metabolic process.
In all, 58 differentially expressed proteins were identified in the placental cotyledon during late pregnancy, including thirty-eight up-regulated proteins and twenty down-regulated proteins (Table 7). These differentially expressed proteins mainly functioned in the areas of energy production and conversion, amino acid transport and metabolism, translation, ribosomal structure and biogenesis and post-translational modification, protein turnover and as chaperones (Fig. 2(b)). Specifically, up-regulated proteins were located in the extracellular exosome, cytosol and nucleus, and were involved in Poly (A) RNA and DNA binding, structural constituent of ribosome, inflammatory response and regulation of lipid metabolic process (Fig. 3(b))

The top ten enrichment pathways of differentially expressed proteins identified are presented in Fig. 4. During early gestation, signals including glycogen degradation, phosphatidylinositol 3 kinase $(\mathrm{PI} 3 \mathrm{~K}) /$ non-specific serine/threonine protein kinase (AKT) and G2/M DNA damage checkpoint regulation were affected by intake restriction, whereas EIF2 signalling, 
Table 4. Serum parameters and placental nitric oxide (NO) concentration in pregnant goats $\dagger$ (Mean values and standard deviations)

\begin{tabular}{|c|c|c|c|c|c|c|c|c|}
\hline \multirow[b]{3}{*}{ Items } & \multicolumn{4}{|c|}{ Trial 1} & \multicolumn{4}{|c|}{ Trial 2} \\
\hline & \multicolumn{2}{|c|}{$C G$} & \multicolumn{2}{|c|}{$R G$} & \multicolumn{2}{|c|}{$C G$} & \multicolumn{2}{|c|}{$R G$} \\
\hline & Mean & $\mathrm{SD}$ & Mean & SD & Mean & SD & Mean & $\mathrm{SD}$ \\
\hline VEGF $(n g / l)$ & 428 & 53.6 & 386 & $30 \cdot 2$ & 405 & $40 \cdot 1$ & 360 & $5 \cdot 51$ \\
\hline TBA $(\mu \mathrm{mol} / /)$ & $32 \cdot 3$ & $2 \cdot 01$ & $33 \cdot 6$ & 5.02 & 40.5 & $22 \cdot 4$ & $32 \cdot 3$ & 5.90 \\
\hline $\mathrm{NO}(\mu \mathrm{mol} / \mathrm{l})$ & 107 & 23.4 & $214^{\star}$ & $40 \cdot 9$ & 229 & $24 \cdot 0$ & 180 & 65.5 \\
\hline INOS (U/ml) & $16 \cdot 1$ & $2 \cdot 32$ & $16 \cdot 6$ & 0.30 & $17 \cdot 8$ & 1.29 & $15 \cdot 6$ & 2.25 \\
\hline TNOS (U/ml) & $15 \cdot 6$ & 0.92 & $14 \cdot 3$ & 1.43 & 17.5 & $2 \cdot 36$ & $19 \cdot 2$ & 0.62 \\
\hline No. of uterine caruncle ( $\mu \mathrm{mol} / \mathrm{g}$ protein) & $21 \cdot 3$ & 10.9 & $10 \cdot 1$ & $5 \cdot 61$ & $15 \cdot 8$ & 6.56 & $14 \cdot 3$ & 9.97 \\
\hline No. of cotyledon ( $\mu \mathrm{mol} / \mathrm{g}$ protein) & 50.8 & $10 \cdot 4$ & 34.9 & $6 \cdot 74$ & $20 \cdot 1$ & 7.74 & $19 \cdot 3$ & 4.91 \\
\hline
\end{tabular}

CG, control group; RG, restricted group; VEGF, vascular endothelial growth factor; TBA, total bile acid; INOS, inducible nitric oxide synthase; TNOS, total nitric oxide synthase.

Mean: * $P<0.05$.

† $n$ 6: $\mathrm{CG}$ and $\mathrm{RG}$.

Table 5. Expression of genes associated with angiogenesis in the placentome of pregnant goats* (Mean values and standard deviations)

\begin{tabular}{|c|c|c|c|c|c|c|c|c|}
\hline \multirow[b]{3}{*}{ Items } & \multicolumn{4}{|c|}{ Trial 1} & \multicolumn{4}{|c|}{ Trial 2} \\
\hline & \multicolumn{2}{|c|}{ CG } & \multicolumn{2}{|c|}{$R G$} & \multicolumn{2}{|c|}{ CG } & \multicolumn{2}{|c|}{$R G$} \\
\hline & Mean & SD & Mean & SD & Mean & SD & Mean & SD \\
\hline \multicolumn{9}{|c|}{ Uterine caruncle } \\
\hline VEFGA & 1.19 & 0.68 & 1.01 & 0.23 & 1.19 & 0.56 & 0.92 & 0.59 \\
\hline$K D R$ & $1 \cdot 13$ & 0.66 & 1.03 & 0.39 & 1.03 & 0.31 & 1.62 & 0.41 \\
\hline NOS1 & 1.19 & 0.62 & 0.59 & 0.16 & 1.09 & 0.45 & 1.65 & 0.75 \\
\hline NOS2 & 1.20 & 0.46 & 3.08 & 1.69 & 1.06 & 0.54 & 0.98 & 0.14 \\
\hline \multicolumn{9}{|l|}{ Cotyledon } \\
\hline VEFFA & 1.09 & 0.60 & 0.89 & 0.24 & $1 \cdot 14$ & 0.54 & 0.59 & 0.27 \\
\hline$K D R$ & $1 \cdot 14$ & 0.44 & 0.92 & 0.16 & 1.09 & 0.64 & 0.94 & 0.52 \\
\hline NOS1 & $1 \cdot 16$ & 0.29 & 0.85 & 0.59 & 1.06 & 0.31 & 1.06 & 0.41 \\
\hline NOS2 & 1.03 & 0.18 & 1.42 & 0.87 & 1.03 & 0.22 & 1.00 & 0.56 \\
\hline
\end{tabular}

CG, control group; RG, restricted group; VEGFA, vascular endothelial growth factor $\mathrm{A} ; K D R$, kinase insert domain receptor; NOS1, nitric oxide synthase 1 ; NOS2, nitric oxide synthase 2.

* $n$ 6: CG and RG.

regulation of eukaryotic translation initiation factor 4 (eIF4) and p70S6K signalling and mammalian target of rapamycin (mTOR) signalling were affected by feed intake restriction during late pregnancy.

Interactive network analysis of the differentially expressed proteins of placental cotyledon in goats during early gestation showed that the up-regulated proteins, such as EIF4E, collagen family members and AKR1B1, were related to proliferation and fission of trophoblast cell and the placenta angiogenesis (Fig.5(a)). Meanwhile, interactive network analysis of the placental cotyledon during late pregnancy indicated that up-regulated proteins such as mitogen-activated protein kinase 1 (ERK1/2) and 1-phosphatidylinositol 4,5-bisphosphate phosphodiesterase $\gamma$-2 (PLCG2) were related to placenta formation, blood flow regulation and embryonic development (Fig. 5(b)). In addition, down-regulated proteins, such as RNA-binding protein 4 isoform X1 (RBM4), Rho-related GTP-binding protein rhoc (RHOC) and voltage-dependent anion-selective channel protein 1 (VDAC1), interacted together to regulate placental trophoblastic cell migration, anion transport, apoptotic process and vascular blood flow regulation.

\section{Discussion}

In the present study, feed intake restriction during early pregnancy allowed both the development of placentae and the growth of fetuses. The high positive correlation between fetal weight and placental and cotyledon weight concurred with previous studies in goats and cows ${ }^{(19,24)}$. Heasman et al. ${ }^{(25)}$ have also observed a higher placental weight with the abundance of placentomes in energy-restricted sheep without difference in fetal birth weight. Our results are partly consistent with those of Steyn et al. ${ }^{(27)}$, who observed an increment of placental growth without differences in fetal weight of sheep that received reduced nutrition during early gestation. The synergetic adaptations in the weight of placenta, uterine caruncle and cotyledon rather than their numbers contributed to the enhanced fetal weight, suggesting that placentome function such as nutrient transport efficiency may be boosted by feed intake restriction at early gestation. Limited feeding promoted the placental weight of goats, but inhibited the growth of fetuses during late pregnancy. Redmer et al. ${ }^{(35)}$ have also observed the same phenomenon in adolescent sheep. However, Osgerby et $a l .{ }^{(26)}$ have ever reported that the placental weight is 
Table 6. Differentially expressed proteins in the placental cotyledon of goats during early gestation*

\begin{tabular}{|c|c|c|c|c|}
\hline Names of proteins & $\begin{array}{l}\mathrm{NCBI} \\
\text { accession }\end{array}$ & $\begin{array}{l}\text { Repetitive peptides } \\
\quad(95 \%)\end{array}$ & $\begin{array}{l}\mathrm{RG}: \mathrm{CG} \\
\text { ratio }\end{array}$ & $\begin{array}{l}\text { Expression } \\
\text { change }\end{array}$ \\
\hline Aldose reductase & gil926690679 & 40 & 2.86 & Up \\
\hline $\begin{array}{l}\text { Tyrosine 3-monooxygenase/tryptophan } \\
\text { 5-monooxygenase activation protein zeta polypeptide, } \\
\text { partial }\end{array}$ & gil695001355 & 20 & $1 \cdot 23$ & Up \\
\hline LOW-QUALITY PROTEIN: collagen $a-1$ (XVIII) chain & gil926684173 & 14 & 1.21 & Up \\
\hline LOW-QUALITY PROTEIN: collagen $a-1(\mathrm{VI})$ chain & gil548452361 & 9 & $2 \cdot 12$ & Up \\
\hline Nucleobindin-2 & gil548495017 & 9 & 1.49 & Up \\
\hline $\begin{array}{l}\text { Glutamine-fructose-6-phosphate aminotransferase } \\
\text { (isomerising) } 1\end{array}$ & gil926704528 & 8 & 1.45 & Up \\
\hline Adenosylhomocysteinase & gil926707708 & 8 & 1.21 & Up \\
\hline Translationally controlled tumour protein & gil926705759 & 6 & 1.25 & Up \\
\hline Prothymosin $a$ & gil926686110 & 6 & 1.23 & Up \\
\hline Decorin precursor & gil550821984 & 5 & 1.57 & Up \\
\hline 14-3-3 Protein sigma & gil548455420 & 5 & 1.34 & Up \\
\hline Legumain & gil548513966 & 4 & 1.78 & Up \\
\hline Phosphoglucomutase-2 & gil926693811 & 4 & 1.45 & Up \\
\hline $\begin{array}{l}\text { Kynurenine/ } a \text {-aminoadipate } \\
\text { aminotransferase, mitochondrial isoform X2 }\end{array}$ & gil926698836 & 4 & 1.39 & Up \\
\hline Synaptic vesicle membrane protein VAT-1 homolog & gil926717165 & 4 & 1.22 & Up \\
\hline Serine/threonine-protein phosphatase CPPED1 & gil548519926 & 3 & 1.68 & Up \\
\hline Coactosin-like protein & gil548502530 & 3 & 1.43 & Up \\
\hline Peroxidasin homolog & gil926700288 & 3 & 1.32 & Up \\
\hline Osteoglycin & gil339521885 & 2 & 1.78 & Up \\
\hline Sulfhydryl oxidase 1 & gil926711770 & 2 & 1.53 & Up \\
\hline Triosephosphate isomerase & gil926692863 & 2 & 1.29 & Up \\
\hline p97Bcnt protein & gil550822062 & 2 & 1.27 & Up \\
\hline Glycogen debranching enzyme & gil926688039 & 2 & 1.24 & Up \\
\hline Protein HEXIM2 & gil548509482 & 2 & 1.23 & Up \\
\hline Protein S100-A10 & gil548457627 & 2 & 1.22 & Up \\
\hline H/ACA ribonucleoprotein complex subunit 4 & gil926728460 & 2 & 1.22 & Up \\
\hline Heterochromatin protein 1-binding protein 3 & gil926686512 & 2 & 1.21 & Down \\
\hline Uncharacterised protein LOC102181082 & gil926722049 & 31 & 0.58 & Down \\
\hline LOW-QUALITY PROTEIN: plectin & gil926708041 & 18 & 0.76 & Down \\
\hline Eukaryotic initiation factor $4 \mathrm{~A}-\mathrm{I}$ & gil548507923 & 14 & 0.75 & Down \\
\hline Keratin, type II cytoskeletal 5 isoform X2 & gil926730618 & 14 & 0.52 & Down \\
\hline Fatty acid synthase & gil550822300 & 9 & 0.72 & Down \\
\hline Chromodomain-helicase-DNA-binding protein 4 isoform X2 & gil548468327 & 5 & 0.67 & Down \\
\hline Keratin, type I cytoskeletal 10 & gil926716364 & 4 & 0.63 & Down \\
\hline Methionine-trna ligase, cytoplasmic isoform X3 & gil548466036 & 3 & 0.77 & Down \\
\hline Placental prolactin-related protein 3-like & gil548518550 & 3 & 0.75 & Down \\
\hline DNA topoisomerase $2-a$ & gil548508944 & 3 & 0.70 & Down \\
\hline ATP-dependent RNA helicase $\mathrm{A}$ isoform $\mathrm{X} 1$ & gil548499423 & 3 & 0.69 & Down \\
\hline Replication factor C subunit 2 & gil926724451 & 2 & 0.79 & Down \\
\hline $\begin{array}{l}\text { Golgi-specific brefeldin A-resistance guanine } \\
\text { nucleotide exchange factor } 1 \text { isoform X1 }\end{array}$ & gil926724854 & 2 & 0.79 & Down \\
\hline Leucine-rich PPR motif-containing protein, mitochondrial & gil926704023 & 2 & 0.79 & Down \\
\hline Tubulin-folding cofactor B isoform X2 & gil926714144 & 2 & 0.79 & Down \\
\hline Dynamin-1-like protein isoform X2 & gil926692458 & 2 & 0.78 & Down \\
\hline Phosphoenolpyruvate carboxykinase [GTP], mitochondrial & gil926701829 & 2 & 0.72 & Down \\
\hline Serine/threonine-protein kinase 3 & gil926708844 & 2 & 0.71 & Down \\
\hline COP9 signalosome complex subunit 4 & gil926694369 & 2 & 0.71 & Down \\
\hline Trifunctional enzyme subunit $a$, mitochondrial & gil548486563 & 2 & 0.70 & Down \\
\hline Carboxypeptidase A4 & gil926690647 & 2 & 0.70 & Down \\
\hline 2'-5'-Oligoadenylate synthase 1 & gil926712688 & 2 & 0.68 & Down \\
\hline Multifunctional protein ADE2 isoform X2 & gil926694027 & 2 & 0.68 & Down \\
\hline
\end{tabular}

$R G$, restricted group; $C G$, control group.

* This table contains quantitative information for proteins that were at least $>1.2$ up-regulated or at least $<0.8$ down-regulated in early pregnant goats with feed intake restriction.

reduced in under-fed ewes receiving $70 \%$ of their estimated requirements. The contrary responses in development of placentae and fetuses in late gestation indicate that a combination of factors originating from maternal placental and fetal sources act together to regulate the growth of fetuses. A reduction of blood vessels in the cytoledon of restricted goats was also observed in this study. This inferred that the nutrient transfer rate from mother to fetus had been deceased and could partly explain the cause of intra-uterine growth restriction at this stage.

To further check whether feed intake restriction influenced placental or embryonic growth via maternal humoral factors, we measured VEGF, TAB, NO and NOS in the serum and related angiogenesis genes in the placentome of pregnant goats. The NO radical is synthesised by the action of the 
(a)

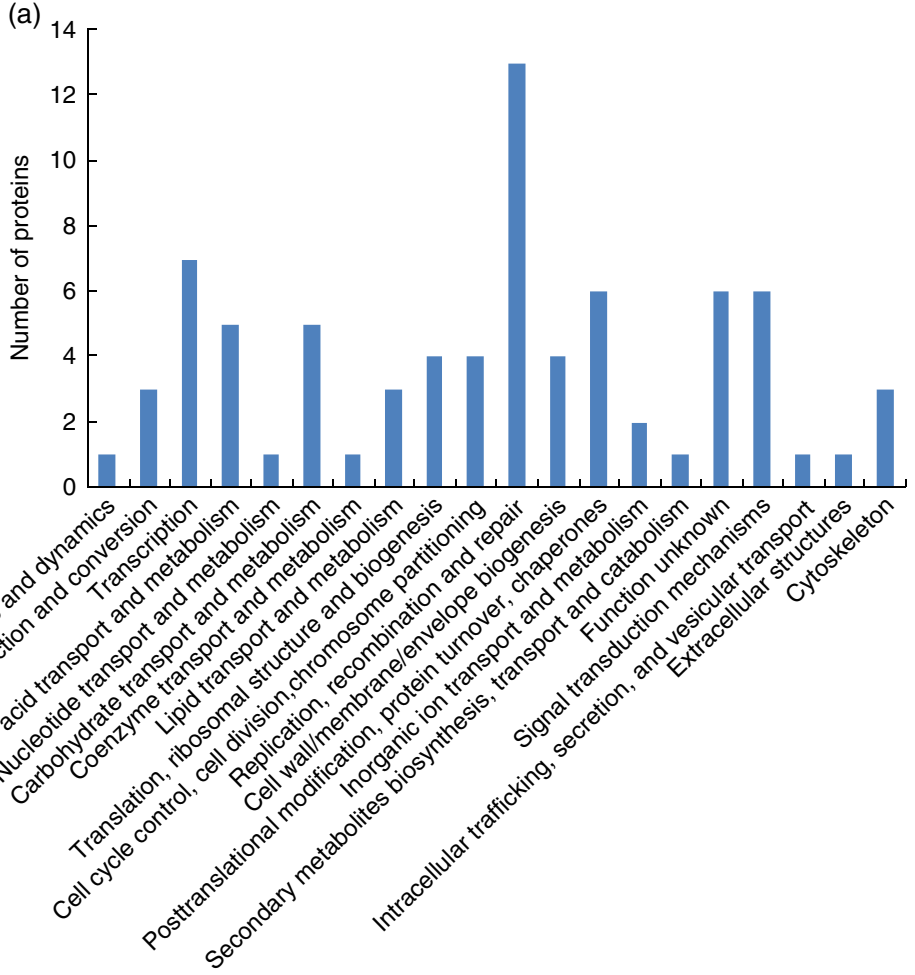

(b)
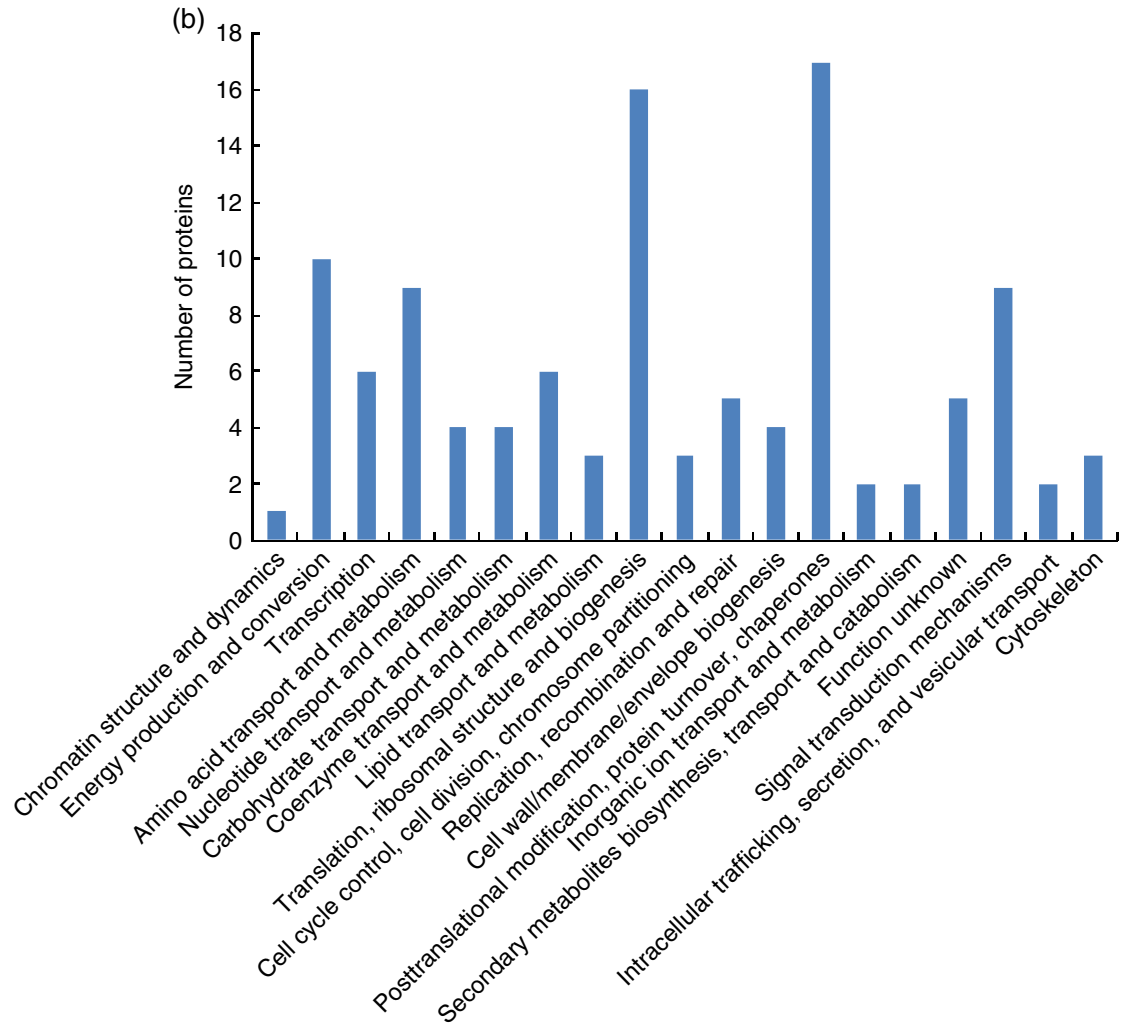

Fig. 2. Functional classification of the differentially expressed proteins in cotyledon of goats in early gestation (a) and late gestation (b).

enzyme NOS and iNOS becomes a dominant NOS isoform during early pregnancy. It is reported that serum iNOS is greater in intra-uterine growth retardation pregnancies and correlates positively with insulin resistance ${ }^{(36)}$, which is helpful to increase nutrition availability in maternal circulation. Fortunately, we found that circulating $\mathrm{NO}$ of maternal goats was increased during early pregnancy, accompanied by more NOS 2 transcription in uterine caruncle. Previous research has shown that 
(a)

Cellular component
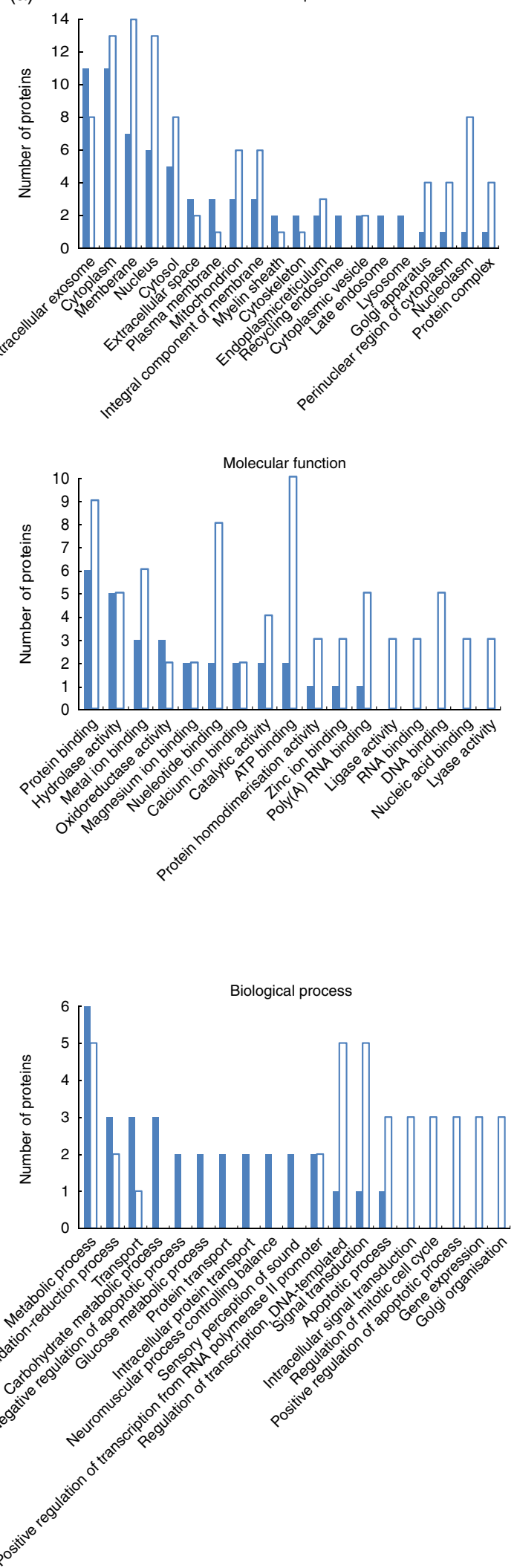

(b) Cellular component

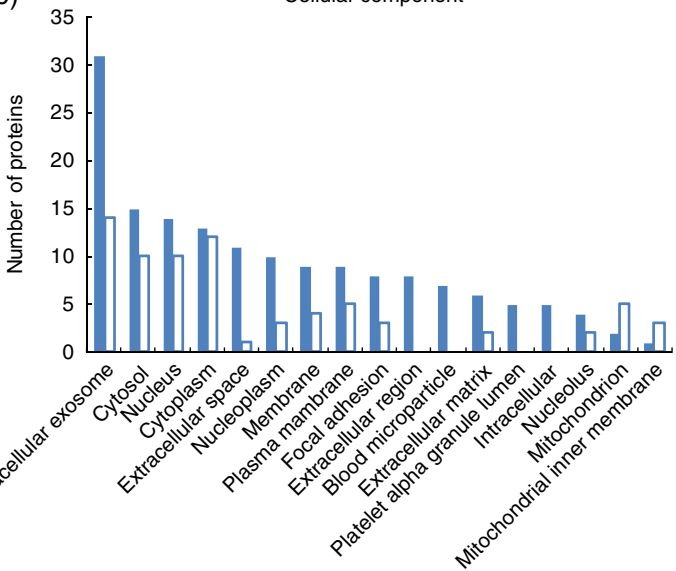

Molecular function

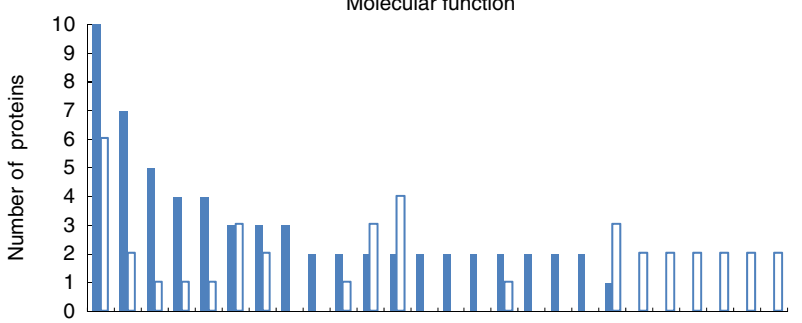

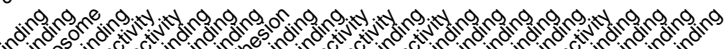

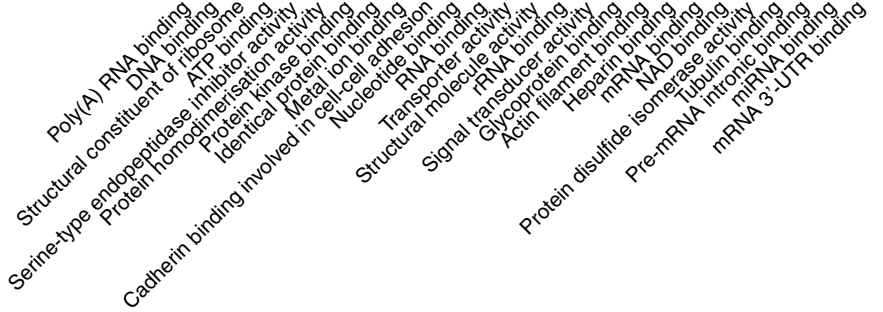

Biological process
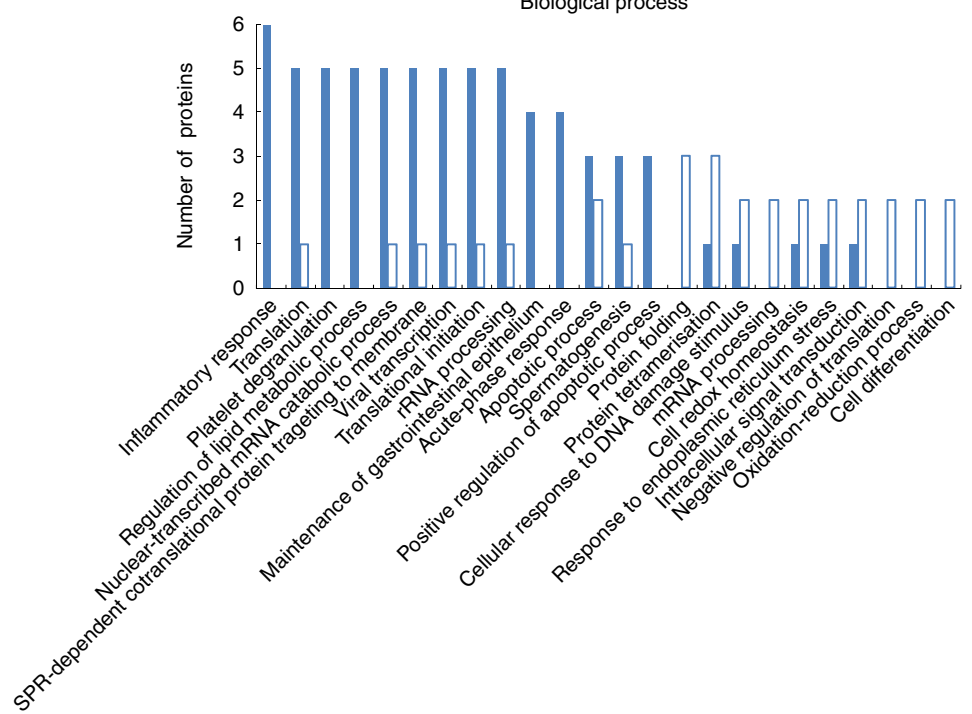

Fig. 3. Classification of the differentially expressed proteins in cotyledon of goats during early gestation (a) and late gestation (b). $\square$, Up; $\square$, down. 
Table 7. Differentially expressed proteins in the placenta cotyledon of goats during late pregnancy*

\begin{tabular}{|c|c|c|c|c|}
\hline Names of proteins (goat) & $\begin{array}{l}\mathrm{NCBI} \\
\text { accession }\end{array}$ & $\begin{array}{l}\text { Repetitive peptides } \\
\quad(95 \%)\end{array}$ & $\begin{array}{l}\mathrm{RG}: C G \\
\text { ratio }\end{array}$ & $\begin{array}{l}\text { Expression } \\
\text { change }\end{array}$ \\
\hline Serpin A3-7-like & gil926730011 & 30 & 1.71 & Up \\
\hline Serpin A3-3 isoform $\mathrm{X} 1$ & gil926719635 & 26 & 1.56 & Up \\
\hline Lamin-B1 & gil926696505 & 24 & 1.40 & Up \\
\hline HSP27 protein, partial & gil389620461 & 19 & 1.61 & Up \\
\hline $\begin{array}{l}\text { Short palate, lung and nasal epithelium carcinoma-associated } \\
\text { protein 2B-like }\end{array}$ & gil926707690 & 18 & $2 \cdot 56$ & Up \\
\hline Fatty acid-binding protein, epidermal & gil926708810 & 17 & 1.51 & Up \\
\hline $60 S$ acidic ribosomal protein $\mathrm{P} 2$ & gil548528705 & 17 & 1.22 & Up \\
\hline Cation-independent mannose-6-phosphate receptor & gil926701295 & 14 & 1.53 & Up \\
\hline Ras-related protein Rab-7a & gil554790259 & 13 & 1.26 & Up \\
\hline $\begin{array}{l}\text { Dolichyl-diphosphooligosaccharide-protein glycosyltransferase } \\
\text { subunit } 1\end{array}$ & gil926721159 & 12 & 1.42 & Up \\
\hline Core histone macro-H2A.1 & gil548474455 & 11 & 1.30 & Up \\
\hline Unconventional myosin-lb isoform $\mathrm{X} 2$ & gil548454324 & 11 & 1.24 & Up \\
\hline Peroxiredoxin-2 & gil926695256 & 10 & 1.33 & Up \\
\hline $60 S$ ribosomal protein L4 & gil548481072 & 9 & 1.48 & Up \\
\hline Ceruloplasmin & gil548451476 & 9 & 1.43 & Up \\
\hline Complement $\mathrm{C} 4$ & gil926721902 & 9 & 1.34 & Up \\
\hline Creatine kinase U-type, mitochondrial & gil548513903 & 8 & 1.24 & Up \\
\hline Plasma membrane calcium-transporting atpase 4 -like & gil926710843 & 7 & $2 \cdot 91$ & Up \\
\hline Serpin A3-3-like & gil926730665 & 7 & 1.48 & Up \\
\hline Galectin-1 & gil926693061 & 7 & 1.31 & Up \\
\hline Flavin reductase (NADPH) & gil926713915 & 7 & 1.25 & Up \\
\hline $\begin{array}{l}\text { Serine/threonine-protein phosphatase } 2 \mathrm{~A} \text { catalytic subunit beta } \\
\text { isoform }\end{array}$ & gil926725758 & 6 & 1.37 & Up \\
\hline Scaffold attachment factor B1-like & gil926695684 & 6 & 1.27 & Up \\
\hline $40 S$ ribosomal protein S4-like & gil926728298 & 6 & $1 \cdot 27$ & Up \\
\hline Protein S100-A10 & gil548457627 & 5 & 1.25 & Up \\
\hline 1-Phosphatidylinositol 4,5-bisphosphate phosphodiesterase $\gamma$-2 & gil926713232 & 4 & 1.31 & Up \\
\hline $40 S$ ribosomal protein $\mathrm{S} 19$ & gil548504758 & 4 & 1.23 & Up \\
\hline Protein AHNAK2 & gil926719909 & 4 & 1.21 & Up \\
\hline $60 S$ ribosomal protein $\mathrm{L} 11$ isoform $\mathrm{X} 1$ & gil926686446 & 3 & 1.44 & Up \\
\hline$a-$ Adducin isoform $\mathrm{X} 10$ & gil926694622 & 3 & 1.32 & Up \\
\hline Mitogen-activated protein kinase 1 & gil936976214 & 3 & 1.29 & Up \\
\hline $15-k D a$ selenoprotein & gil926688216 & 3 & 1.28 & Up \\
\hline Bisphosphoglycerate mutase & gil926690684 & 2 & 1.63 & Up \\
\hline Programmed cell death protein 5 & gil926714554 & 2 & 1.44 & Up \\
\hline Kininogen- 1 isoform $\times 3$ & gil548450536 & 2 & 1.37 & Up \\
\hline Antimicrobial peptide NK-lysin-like isoform X2 & gil548486107 & 2 & 1.34 & Up \\
\hline LOW-QUALITY PROTEIN: bola-like protein 2 & gil548520415 & 2 & 1.21 & Up \\
\hline RNA-binding protein 12 & gil926707624 & 2 & 1.21 & Up \\
\hline Protein disulfide-isomerase A4 & gil926690840 & 48 & 0.48 & Down \\
\hline Ubiquitin-like modifier-activating enzyme 1 & gil926728935 & 38 & 0.76 & Down \\
\hline Serpin B6-like & gil926730060 & 34 & 0.57 & Down \\
\hline Heterogeneous nuclear ribonucleoproteins $\mathrm{A} 2 / \mathrm{B} 1$ isoform $\mathrm{X} 2$ & gil548463546 & 24 & 0.43 & Down \\
\hline Voltage-dependent anion-selective channel protein 1 & gil926698033 & 19 & 0.78 & Down \\
\hline $40 \mathrm{~S}$ ribosomal protein S3 & gil548496090 & 16 & 0.68 & Down \\
\hline Trifunctional enzyme subunit $a$, mitochondrial & gil548486563 & 15 & 0.66 & Down \\
\hline Camp-dependent protein kinase type II- $a$ regulatory subunit & gil926720476 & 14 & 0.79 & Down \\
\hline Endoplasmic reticulum resident protein 44 & gil548477505 & 10 & 0.59 & Down \\
\hline Probable 2-ketogluconate reductase & gil926722447 & 7 & 0.70 & Down \\
\hline Argininosuccinate lyase & gil550821852 & 7 & 0.68 & Down \\
\hline Prefoldin subunit 3 & gil926728503 & 5 & 0.76 & Down \\
\hline Myosin phosphatase Rho-interacting protein isoform X1 & gil926716910 & 5 & 0.74 & Down \\
\hline Rho-related GTP-binding protein rhoc & gil926687802 & 4 & 0.66 & Down \\
\hline DAZ-associated protein 1 & gil926697733 & 3 & 0.78 & Down \\
\hline Translin isoform $\mathrm{X} 1$ & gil548454302 & 3 & 0.75 & Down \\
\hline Inad-like protein isoform $\mathrm{X} 1$ & gil926688579 & 2 & 0.77 & Down \\
\hline Dehydrogenase/reductase SDR family member 4 & gil926701835 & 2 & 0.76 & Down \\
\hline RNA-binding protein 4 isoform $\mathrm{X}_{1}$ & gil926727434 & 2 & 0.73 & Down \\
\hline Serine hydroxymethyltransferase, cytosolic & gil926716542 & 2 & 0.68 & Down \\
\hline
\end{tabular}

$R G$, restricted group; CG, control group.

* This table contains quantitative information for proteins that were at least $>1.2$ up-regulated or at least $<0.8$ down-regulated in late pregnant goats with feed intake restriction. 

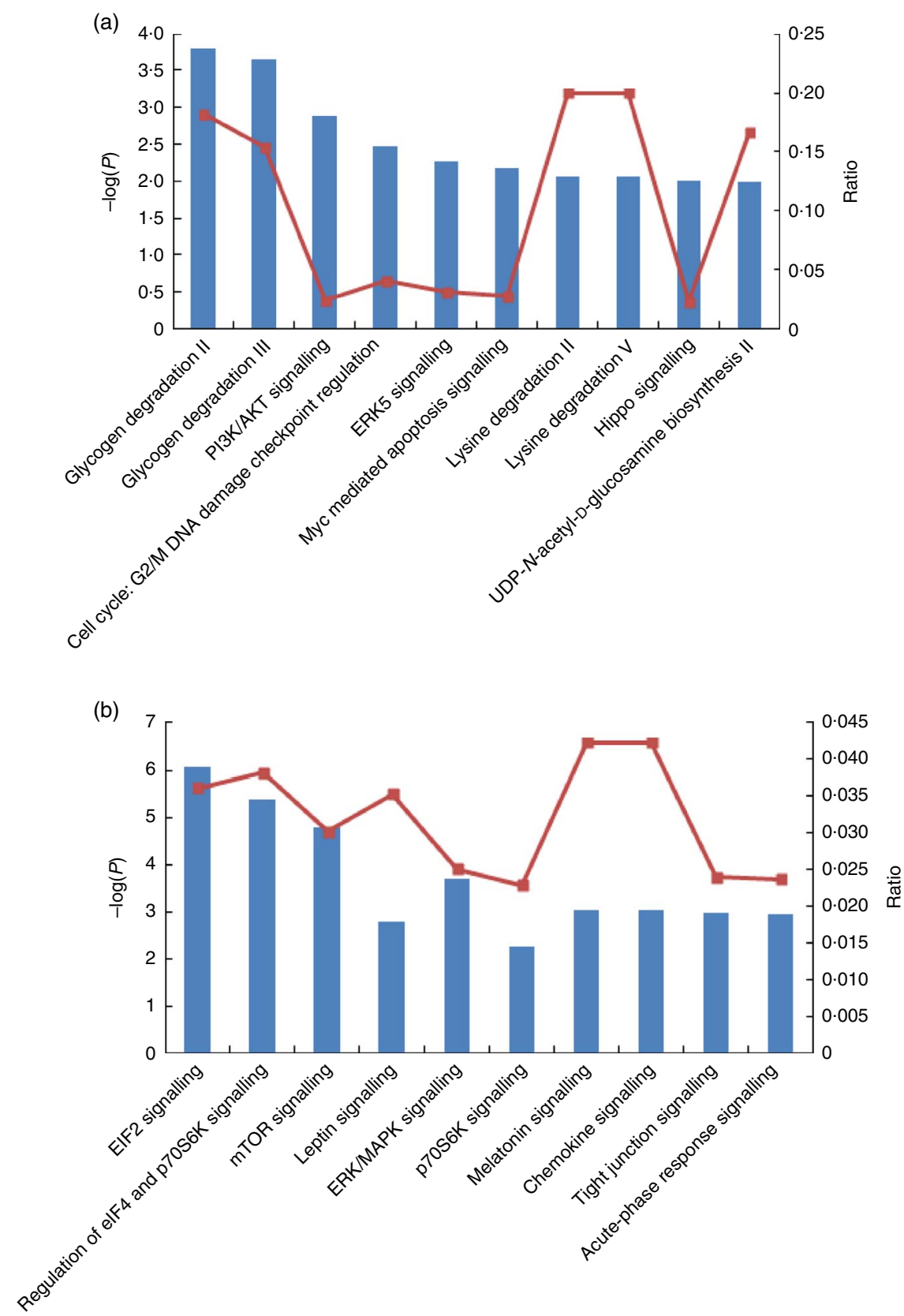

Fig. 4. Enriched pathways of differential expressed proteins in cotyledon of goats during early pregnancy (a) and during late pregnancy (b). mTOR, mammalian target of rapamycin; PI3K, phosphatidylinositol 3 kinase; AKT, non-specific serine/threonine protein kinase; ERK5, mitogen-activated protein kinase 5.

$\mathrm{NO}$ production is required for normal embryonic development and works as a signal to stimulate local vasodilation and capillary permeability ${ }^{(37)}$. The NO also plays important roles in female reproduction, ovarian follicular development, secretion of ovarian hormones, implantation, pregnancy maintenance and parturition ${ }^{(38-40)}$. Our results reflected that, during early pregnancy, nutrient restriction induced the embryo producing $\mathrm{NO}$ as a messenger molecule to maintain the pregnancy and embryonic growth by increasing placental blood flow and nutrient supply.

In this study, we successfully identified a total of fifty differentially expressed proteins (twenty-seven up-regulated and twenty-three down-regulated) in the placentome of malnourished goats during early gestation. We also discovered that some important functional proteins including AKR1B1, EIF4E and collagen family members, which are related to proliferation and division of trophoblast cells and placental angiogenesis, were upregulated after IPA network analysis. Increasing amounts of AKR1B1 expression were particularly significant. AKR1B1 belongs to the aldo-keto reductase family and is expressed in bovine endometrium. It works as a candidate enzyme for controlling the sufficient and timely production of PGF $2 \alpha$ being responsible for recognition of pregnancy ${ }^{(41,42)}$. Expression levels of collagen, collagen type I, collagen type VI, COL6A1 and COL18A1 were increased in early-pregnant goats experiencing feed intake restriction. All of them belong to the collagen 
(a)

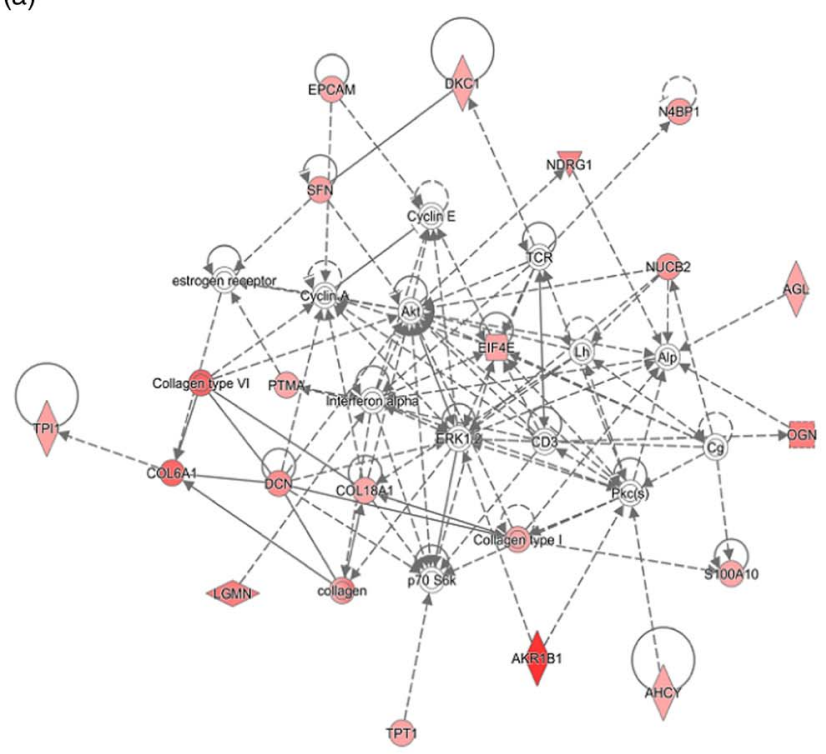

(b)

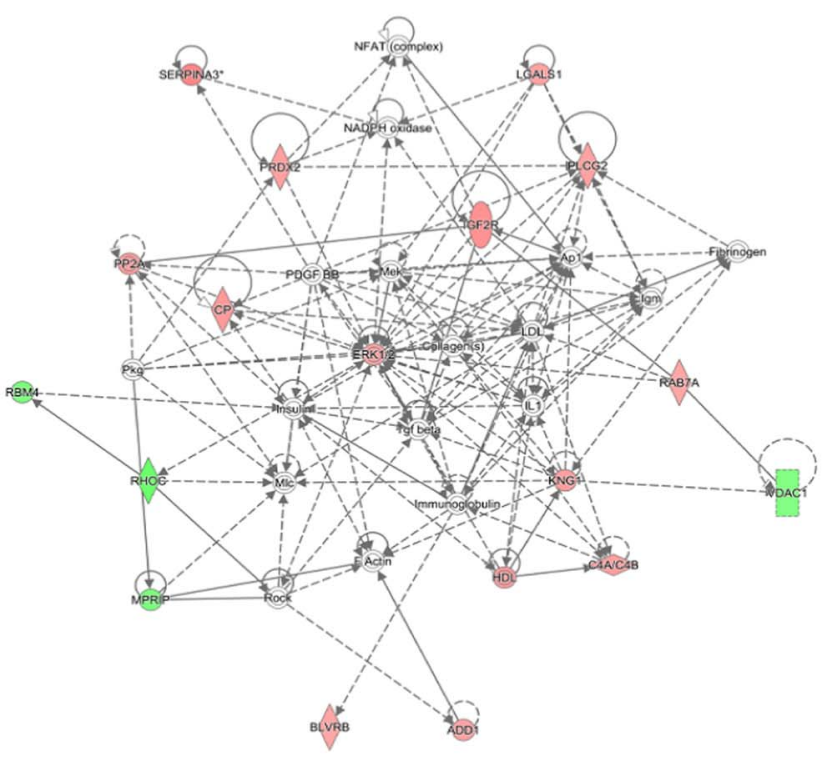

Fig. 5. Network of protein interactions among the differentially expressed proteins in cytoledon of goats during early pregnancy (a) and during late pregnancy (b).

superfamily, which are components of extra-cellular matrix and are involved in the regulation of cell proliferation, differentiation and gene expression. Previous studies have shown that types I, III, IV, V and XVIII can be detected in the human placenta ${ }^{(43,44)}$. The increase of collagen family members suggested that the synthesis of collagen and the extra-cellular matrix-receptor interaction may be enhanced. EIF4E is located in the centre of the network and participated in the PI3K/AKT pathway, which was strongly influenced by nutrient restriction during early pregnancy. EIF4E has an important role in the regulation of initial stage of the normal synthesis of cap structure-dependent protein and promotes the proliferation and survival of trophoblast cells. EIF4E gene silencing in placental explants can accelerate cell death and inhibit cell cycle ${ }^{(45)}$. Up-regulation of EIF4E and PI3K/AKT pathway indicated that the proliferation and survival of placental cells were improved to maintain the development of the placentome.

During late pregnancy, fifty-eight differentially expressed proteins were identified in the placentome, comprising thirtyeight up-regulated and twenty down-regulated proteins. Specifically, up-regulated proteins ERK1/2 and PLCG2 were found to be related to placental formation, blood flow regulation and embryonic development. Down-regulated proteins RHOC, RBM4a and VDAC1 were related to trophoblast migration and vascular regulation according to the IPA network. One potential function of ERK1/2 on the development of placentae may be direct action. Previous research showed that in the condition of intra-uterine growth restriction induced by dexamethasone, abnormal placental and embryonic development may be associated with reduced Akt and ERK1/2 activities, manifesting as cell survival inhibition or apoptosis ${ }^{(46)}$. Another possible regulatory manner of ERK1/2 on the development of placentae might be via blood vessels and blood flow; Wu et al. ${ }^{(47)}$ have founded that ERK inhibitor U0126 significantly attenuates the vasodilator response induced by spinal cord stimulation. Zheng et al. ${ }^{(48)}$ have also noted that activation of the ERK1/2-mitogenactivated protein kinase $3 / 1$ pathway is critical for fibroblast growth factor 2 and VEGF-stimulated ovine fetoplacental endothelial cell proliferation. PLCG2 is involved in leptin, ERK/ MAPK, p70S6K, melatonin and chemokine pathways, and its abundance was increased by nutrient restriction in this study. It has been reported that PLCG2 is an important regulator of embryonic cerebral cortices ${ }^{(49)}$ and osteoclast ${ }^{(50)}$ development by mediating integrin receptor signalling. RHOC expression in the cotyledon of malnourished goats was inhibited in this study. As a member of the Rho family of small G proteins, RHOC and RHOA are required for epidermal growth factor-mediated trophoblast cell migration and obligatory for epidermal growth factor action ${ }^{(51)}$. RBM4a usually participates in translation suppression during muscle cell differentiation ${ }^{(52)}$. Its role in placental development needs to be revealed in the future. VDAC1 is involved in calcium metabolism of the placenta and regulates the balance of mitochondrial $\mathrm{Ca}^{2+}$. VDAC1 is selectively localised in the basal membrane fraction of human placenta, and its expression in the placenta from pregnancies with fetal growth restriction is up-regulated by hypoxia ${ }^{(53)}$. Less abundances of RHOC and VDAC1 in cotyledon of under-fed goats during late pregnancy indicated that trophoblast cell migration, vascular nutrient exchange rate and calcium ion homoeostasis might have been disrupted.

\section{Conclusion}

Feed intake restriction during early gestation regulated placental and fetal development, increased serum NO production and regulated glycogen degradation, PI3K/AKT and cell cycle signalling transduction pathways, as well as functional proteins EIF4E, collagen family members and AKR1B1, in the placentome of goats. Nutrient restriction during late gestation increased placental weight, but induced fetal growth restriction. Decreased blood vessel density in cotyledon, differential 
signalling pathways of EIF2, regulation of eIF4 and p70S6K, mTOR, leptin and ERK/MAPK, and related key proteins ERK1/2, PLCG2, RHOC, VDAC1 and RBM4 may be associated with placental function. It is apparent that effects of nutrient restriction on goat placental traits and proteome, and fetal development, are stage-specific. The regulatory mechanism of differentially expressed proteins and related pathways identified by proteomics needs to be evaluated in the future. Because goats are twin-bearing animals, nutrient management during pregnancy is crucial and further knowledge of the effects of feed restriction will enrich the potential for fetal programming in mammals.

\section{Acknowledgements}

This work was jointly supported by the National Natural Science Foundation of China (grant no. 31402105, 31760678), CAS Visiting Professorship for Senior \&Young International Scientists (grant no. 2013Y2GA0010, 2017VBA0026) and Youth Innovation Team Project of ISA, CAS (2017QNCXTD-ZCS). The supporting agency had no role in the design or conduct of the study; collection, analysis or interpretation of the data; or the preparation and approval of the manuscript.

Q. Y. and Z. T. designed the study. J. X. was in charge of data collection. X. W., D. S. and Q. Y. analysed the data and wrote the paper. All authors were involved in the interpretation of the data, critically reviewed the manuscript and approved the final version. Q. Y. and Z. T. were responsible for the manuscript's contents.

None of the authors has any conflicts of interest to declare.

\section{References}

1. Bell AW \& Ehrhardt RA (2002) Regulation of placental nutrient transport and implications for fetal growth. Nutr Res Rev 15, 211-230.

2. Barry JS \& Anthony RV (2008) The pregnant sheep as a model for human pregnancy. Theriogenology 69, 55-67.

3. Fowden AL, Ward JW, Wooding FPB, et al. (2006) Programming placental nutrient transport capacity. J Physiol 572, 5-15.

4. Ward JW, Forhead AJ, Wooding FBP, et al. (2006) Functional significance and cortisol dependence of the gross morphology of ovine placentomes during late gestation. Biol Reprod $\mathbf{7 4}$, 137-145.

5. Sibley CP, Brownbill P, Dilworth M, et al. (2010) Adaptation in placental nutrient supply to meet fetal growth demand: implications for programming. Placenta 31, S70-S74.

6. Wooding FB (1992) Current topic: the synepitheliochorial placenta of ruminants: binucleate cell fusions and hormone production. Placenta 13, 101-113.

7. Igwebuike UM \& Ezeasor DN (2013) The morphology of placentomes and formation of chorionic vinous trees in West African Dwarf goats (Capra hircus). Vet Arbiv 83, 313-321.

8. Igwebuike UM \& Ezeasor DN (2014) Morphological adaptations for histotrophic nutrition in the placenta of West African Dwarf goats. Slov Vet Res 51, 11-19.

9. Igwebuike UM \& Ezeasor DN (2012) Morphological assessment of placentomal trophoblastic epithelium in the placenta of West African Dwarf goats: a light and electron microscopic study. Anim Reprod Sci 136, 61-68.
10. Meuris S, Nagy AM, Delognedesnoeck J, et al. (1995) Temporal relationship between the human chorionic-gonadotropin peak and the establishment of intervillous blood-flow in earlypregnancy. Hum Reprod 10, 947-950.

11. Babu GJJ, Radhakrishna KV, Ramalakshmi BA, et al. (2008) Maternal nutrition in early pregnancy effects placental development. Placenta 29, A55-A55.

12. Jauniaux E, Jurkovic D, Gulbis B, et al. (1994) Investigation of the acid-base-balance of celomic and amniotic fluids in early human-pregnancy. Am J Obstet Gynecol 170, 1365-1369.

13. Genbacev O, Joslin R, Damsky CH, et al. (1996) Hypoxia alters early gestation human cytotrophoblast differentiation/ invasion in vitro and models the placental defects that occur in preeclampsia. J Clin Invest $\mathbf{9 7}, 540-550$.

14. Rodesch F, Simon P, Donner C, et al. (1992) Oxygen measurements in endometrial and trophoblastic tissues during early-pregnancy. Obstet Gynecol 80, 283-285.

15. Burton GJ \& Fowden AL (2012) Review: The placenta and developmental programming: balancing fetal nutrient demands with maternal resource allocation. Placenta 33, Suppl., S23-S27.

16. LangleyEvans SC, Phillips GJ, Benediktsson R, et al. (1996) Protein intake in pregnancy, placental glucocorticoid metabolism and the programming of hypertension in the rat. Placenta 17, 169-172.

17. Spencer NJ, Dickson EJ, Hennig GW, et al. (2006) Sensory elements within the circular muscle are essential for mechanotransduction of ongoing peristaltic reflex activity in guinea-pig distal colon. J Physiol 576, 519-531.

18. Dwyer CM, Calvert SK, Farish M, et al. (2005) Breed, litter and parity effects on placental weight and placentome number, and consequences for the neonatal behaviour of the lamb. Theriogenology 63, 1092-1110.

19. Konyali A, Tolu C, Das G, et al. (2007) Factors affecting placental traits and relationships of placental traits with neonatal behaviour in goat. Anim Reprod Sci 97, 394-401.

20. Gao H, Yallampalli U \& Yallampalli C (2013) Gestational protein restriction affects trophoblast differentiation. Front Biosci (Elite Ed) 5, 591-601.

21. Rebelato HJ, Esquisatto MA, de Sousa Righi EF, et al. (2016) Gestational protein restriction alters cell proliferation in rat placenta. J Mol Histol 47, 203-211.

22. Rutland CS, Latunde-Dada AO, Thorpe A, et al. (2007) Effect of gestational nutrition on vascular integrity in the murine placenta. Placenta 28, 734-742.

23. Daniel Z, Swali A, Emes R, et al. (2016) The effect of maternal undernutrition on the rat placental transcriptome: protein restriction up-regulates cholesterol transport. Genes Nutr 11, 27.

24. Perry VE, Norman ST, Owen JA, et al. (1999) Low dietary protein during early pregnancy alters bovine placental development. Anim Reprod Sci 55, 13-21.

25. Heasman L, Clarke L, Firth K, et al. (1998) Influence of restricted maternal nutrition in early to mid gestation on placental and fetal development at term in sheep. Pediatr Res 44, 546-551.

26. Osgerby JC, Wathes DC, Howard D, et al. (2004) The effect of maternal undernutrition on the placental growth trajectory and the uterine insulin-like growth factor axis in the pregnant ewe. J Endocrinol 182, 89-103.

27. Steyn C, Hawkins P, Saito T, et al. (2001) Undernutrition during the first half of gestation increases the predominance of fetal tissue in late-gestation ovine placentomes. Eur J Obstet Gynecol Reprod Biol 98, 165-170.

28. Redmer DA, Luther JS, Milne JS, et al. (2009) Fetoplacental growth and vascular development in overnourished adolescent sheep at day 50, 90 and 130 of gestation. Reproduction 137, 749-757. 
29. Ehrhardt RA \& Bell AW (1995) Growth and metabolism of the ovine placenta during mid-gestation. Placenta 16, 727-741.

30. Wallace JM, Bourke DA \& Aitken RP (1999) Nutrition and fetal growth: paradoxical effects in the overnourished adolescent sheep. J Reprod Fertil Suppl 54, 385-399.

31. Weidner N, Folkman J, Pozza F, et al. (1992) Tumor angiogenesis: a new significant and independent prognostic indicator in earlystage breast carcinoma. J Natl Cancer Inst 84, 1875-1887.

32. Li C, Tong H, Yan Q, et al. (2016) L-Theanine improves immunity by altering TH2/TH1 cytokine balance, brain neurotransmitters, and expression of phospholipase $\mathrm{C}$ in rat hearts. Med Sci Monit 22, 662-669.

33. Livak KJ \& Schmittgen TD (2001) Analysis of relative gene expression data using real-time quantitative PCR and the 2 (-Delta Delta C(T)) Method. Methods 25, 402-408.

34. Zhang T, Guo Y, Guo X, et al. (2013) Comparative proteomics analysis of placenta from pregnant women with intrahepatic cholestasis of pregnancy. PLOS ONE 8, e83281.

35. Redmer DA, Milne JS, Aitken RP, et al. (2012) Decreasing maternal nutrient intake during the final third of pregnancy in previously overnourished adolescent sheep: Effects on maternal nutrient partitioning and feto-placental development. Placenta 33, 114-121.

36. Morteza A, Abdollahi A \& Bandarian M (2012) Serum nitric oxide syntheses and lipid profile of the mothers with IUGR pregnancies uncomplicated with preeclampsia. Does insulin resistance matter? Gynecol Endocrinol 28, 139-142.

37. Gouge RC, Marshburn P, Gordan BE, et al. (1998) Nitric oxide as a regulator of embryonic development. Biol Reprod 58, 875-879.

38. Dubey PK, Tripathi V, Singh RP, et al. (2012) Expression of nitric oxide synthase isoforms in different stages of buffalo (Bubalus bubalis) ovarian follicles: effect of nitric oxide on in vitro development of preantral follicle. Theriogenology 77, 280-291.

39. Maul H, Longo M, Saade GR, et al. (2003) Nitric oxide and its role during pregnancy: from ovulation to delivery. Curr Pharm Des 9, 359-380.

40. Sagar P, Prasad JK, Prasad S, et al. (2012) Effect of L-arginine methyl ester (L-NAME) on hormonal profile and estrous cycle length in buffaloes (Bubalus bubalis). Trop Anim Health Prod 44, 1697-1702.

41. Madore E, Harvey N, Parent J, et al. (2003) An aldose reductase with 20 alpha-hydroxysteroid dehydrogenase activity is most likely the enzyme responsible for the production of prostaglandin $\mathrm{f} 2$ alpha in the bovine endometrium. $J$ Biol Chem 278, 11205-11212

42. Lacroix Pepin N, Chapdelaine P \& Fortier MA (2013) Evaluation of the prostaglandin $\mathrm{F}$ synthase activity of human and bovine aldo-keto reductases: AKR1A1s complement AKR1B1s as potent PGF synthases. Prostaglandins Other Lipid Mediat 106, 124-132.

43. Rukosuev VS (1992) Immunofluorescent localization of collagen type-I, type-Iii, type-Iv, type- $\mathrm{V}$, fibronectin, laminin, entactin, and heparan-sulfate proteoglycan in human immature placenta. Experientia 48, 285-287.

44. Saarela J, Ylikarppa R, Rehn M, et al. (1998) Complete primary structure of two variant forms of human type XVIII collagen and tissue-specific differences in the expression of the corresponding transcripts. Matrix Biol 16, 319-328.

45. Kitroser E, Pomeranz M, Shochet GE, et al. (2012) The involvement of eukaryotic translation initiation factor $4 \mathrm{E}$ in extravillous trophoblast cell function. Placenta $\mathbf{3 3}$, $717-724$.

46. Ozmen A, Unek G, Kipmen-Korgun D, et al. (2011) The expression of Akt and ERK1/2 proteins decreased in dexamethasone-induced intrauterine growth restricted rat placental development. J Mol Histol 42, 237-249.

47. Wu M, Komori N, Qin C, et al. (2008) Extracellular signalregulated kinase (ERK) and protein kinase $\mathrm{B}$ (AKT) pathways involved in spinal cord stimulation (SCS)-induced vasodilation. Brain Res 1207, 73-83.

48. Zheng J, Wen Y, Song Y, et al. (2008) Activation of multiple signaling pathways is critical for fibroblast growth factor 2- and vascular endothelial growth factor-stimulated ovine fetoplacental endothelial cell proliferation. Biol Reprod $\mathbf{7 8 ,}$ 143-150.

49. Rout UK \& Dhossche JM (2010) Liquid-diet with alcohol alters maternal, fetal and placental weights and the expression of molecules involved in integrin signaling in the fetal cerebral cortex. Int J Environ Res Public Health $\mathbf{7}$, 4023-4036.

50. Epple H, Cremasco V, Zhang K, et al. (2008) Phospholipase Cgamma 2 modulates integrin signaling in the osteoclast by affecting the localization and activation of Src kinase. Mol Cell Biol 28, 3610-3622.

51. Han J, Li L, Hu J, et al. (2010) Epidermal growth factor stimulates human trophoblast cell migration through Rho A and Rho C activation. Endocrinology 151, 1732-1742.

52. Lin JC \& Tarn WY (2009) RNA-binding motif protein 4 translocates to cytoplasmic granules and suppresses translation via argonaute 2 during muscle cell differentiation. $J$ Biol Chem 284, 34658-34665.

53. Oh SY, Hwang JR, Lee Y, et al. (2016) Isolation of basal membrane proteins from BeWo cells and their expression in placentas from fetal growth-restricted pregnancies. Placenta 39, 24-32. 